\title{
The Effect Of Giving Question And Giving Answer Learning Models In Improving Learning Outcome Of Students Class V SD Inpres 12/79 Lonrae Kec Tanete Riattang Timur Kab Bone
}

\author{
Makmur Nurdin ${ }^{1}$ \\ $\left\{\right.$ makmurnurdin@gmail.com $\left.{ }^{1}\right\}$ \\ ${ }^{1}$ PGSD FIP UNM, Indonesia
}

\begin{abstract}
The problem in this study is the low learning outcomes of Social Studies students in grade V SD Inpres 12/79 Lonrae, Tanete Riattang Timur District, Bone Regency. The purpose of the study was to describe the application of the GQGA learning model in improving the social studies learning outcomes of grade V elementary school students. The research approach was a descriptive qualitative approach with a type of CAR consisting of planning, implementation, observation, and reflection. The focus of research is the GQGA learning model and student learning outcomes. The research subjects were teachers and fifth grade students, totaling 23 students consisting of 13 men and 10 women. Data collection techniques using observation, and tests. Data analysis techniques are data reduction, data presentation, and drawing conclusions. The results showed there was an increase in teacher and student activities as well as social studies learning outcomes which were in the good category. So the application of the GQGA learning model can improve the learning process and learning outcomes of students in class V of SD Inpres 12/79 Lonrae, Tanete Riattang Timur District, Bone Regency.
\end{abstract}

Keyword: Social Studies Learning Outcomes, Learning model giving question and giving answer

\section{Introduction}

Social studies learning is one component of basic education in teaching fields. The field of social studies is needed to know the reality, social phenomena and to solve social problems in social life. To develop students' potential, learning must be impressive for students to be able to think critically and learning can be meaningful. Therefore, learning must be created according to the interests and pleasures of students, so students learn effectively and fun. In the Education Unit Level Curriculum (KTSP) in 2006, there were social studies subjects aimed at understanding concepts related to community life and its environment as well as how committed to social and human values.

Social studies learning in elementary schools is expected to develop the potential of students to be sensitive to social problems that occur in the community. Therefore, it is expected that a teacher in teaching social studies must pay attention to the intellectual development of their students. In addition, a teacher is also required to have the ability to instill learning concepts in students and also the teacher needs to master a variety of approaches, methods and models in teaching social studies and be able to apply them well, so that the knowledge, understanding of concepts and the scope of social studies can be mastered 
and understood in primary school. Through the learning model that has been mastered by the teacher, the teacher can create an efficient and effective learning environment in social studies learning.

This expectation is not in accordance with what happened in the field. Based on the documentation of the list of final test scores in the fifth grade students of SD Inpres 12/79 Lonrae in the odd semester of the academic year 2017/2018 presented by the fifth grade teacher, it was stated that out of the 23 students who completed their learning outcomes were 10 people (43.4\%), who incomplete 13 people (56.5\%) of KKM determined in school in social studies subject class $\mathrm{V}$ that is 75 in addition to the document data above the researchers also observed class on January 25, 2018 found several facts in the classroom namely 1) teachers lack creating conditions the class is fun so students are less enthusiastic in learning, 2) learning is centered on the teacher so students are less active in learning, 3) the teacher is not giving questions that are challenging to students so students are not creative.

Based on the problems mentioned above, if it is not handled immediately, it will have an impact on student motivation which will reduce the learning outcomes. Therefore, researchers offer a GQGA learning model that can train students to have the ability and skills to ask and answer questions using pieces of paper. The GQGA learning model is a learning model asking questions and answering questions using pieces of paper as a learning medium. Suprijono (2015: 126) states that "the Giving Question and Getting Answer learning model was developed to train students to have the ability and skills to ask and answer questions".[1]

The GQGA learning model is an implementation of a constructivist learning strategy that places students as subjects in learning. That is, students are able to reconstruct their own knowledge while the teacher is only a facilitator. This learning model is very good for improving students' questioning and answering skills because the questioning and answering activities undertaken by teachers and students in the teaching and learning process are able to foster new knowledge in students.

According to Djamarah (2014: 379) "Giving Question and Getting Answer is to give questions and receive answers. This strategy is very well used to involve students in repeating the subject matter that has been delivered ".[2] The GQGA learning model is a question and answer variation that involves students actively asking questions and giving answers by using a piece of paper to conceptualize questions and answers that will be asked. This learning model is very well used to involve students in repeating the subject matter that has been delivered by the teacher. So students will pay more attention to the subject matter because after explained by the teacher, students must make questions and answer questions given by other students.

This makes students pay attention to the material presented by the teacher, so that students more easily make questions and answer questions from other students. The advantage of this model is that the classroom atmosphere will become more active because students have the opportunity to ask questions that are not yet understood in the subject matter and encourage students to dare to submit their opinions. This learning model is expected to increase student motivation for learning, students do not get bored during the learning process and learning outcomes increase. 


\section{Research Methods}

The research approach is a qualitative approach to the type of research is classroom action research with a cycle method consisting of planning, implementing actions, observation and reflection. The focus of the research is (1) The application of the GQGA Learning model is to ask questions and get answers. Students get two papers from the teacher, then fill out the paper. Paper 1 contains questions and paper 2 contains material that students can explain, (2) The intended social learning outcomes are the abilities possessed by students after the learning process is carried out and are elaborated on the values of student learning outcomes obtained by students in social studies learning after applied the GQGA learning model.

The subjects of this study were teachers and fifth grade students of Inpres 12/79 Lonrae District Tanete Riattang Timur Bone District who were active in the even semester of the academic year 2017/2018 with 23 people consisting of 13 male students and 10 female students. The cycle or flow in this study as follows:

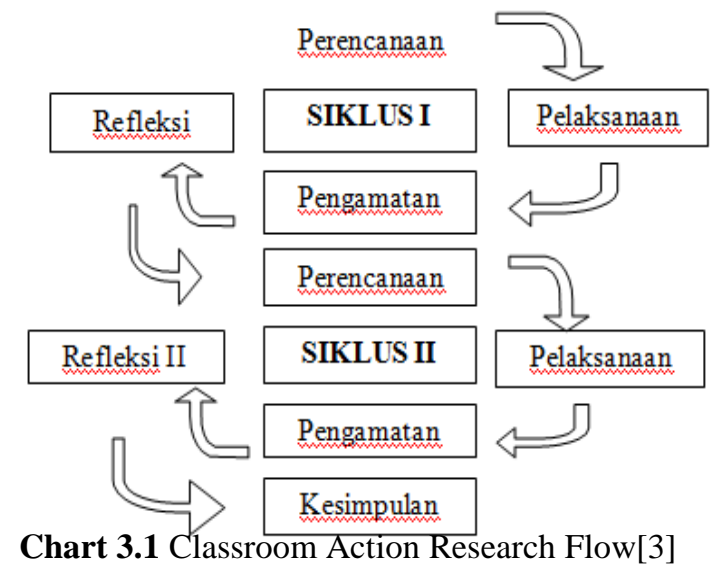

The data presented in this study were obtained by observation, data collection techniques and tests. The collected data were analyzed with qualitative data analysis techniques, one of which is an interactive analysis technique developed by Miles and Huberman [4] through several stages, namely by reducing data, presenting data, drawing conclusions.

Indicators of success in this study are seen from the aspects of the process and aspects of student learning outcomes in social studies learning. From the aspect of the process, it can be seen from the suitability of the steps of the Giving Question and Getting Answer learning model with the activities of teachers and students in social studies learning with good results. While from the aspect of learning outcomes, learning is successful if $75 \%$ of the total students reach the Minimum Mastery Criteria (KKM) set by the teacher board for social studies subjects that is 75 . The criteria used to determine the qualification level of students' social studies learning outcomes and the success of the process teaching teacher as follows:

Table 3.2 Qualification Level of Learning Outcomes[5]

\begin{tabular}{cc}
\hline Percentage of Learning success rate & Qualification \\
\hline$(75-100) \%$ & Good (B) \\
\hline
\end{tabular}




\begin{tabular}{cc}
\hline$(49-74) \%$ & Enough $\odot ~$ \\
\hline$\leq 48 \%$ & Less $(\mathrm{K})$ \\
\hline
\end{tabular}

\section{Discussion}

Before carrying out learning activities in this study, researchers conducted observations in class V of SD Inpres 12/79 Lonrae Tanete Riattang Timur District Bone District the results of the researchers obtained preliminary data in the form of student semester odd test scores in social studies learning with an average value of 65.30 and the percentage of mastery learning $43.4 \%$. From these preliminary data, information is obtained that student learning outcomes in understanding social studies subject matter are still lacking. Based on the stated reality, the researcher compiles a learning design that can help students understand social studies subjects by applying the GQGA learning model.

The GQGA learning model leads to actively involving students to ask questions and provide answers by using paper-cut media to conceptualize questions and answers that will be asked. As stated is "the Giving Question and Getting Answer learning model was developed to train students to have the ability and skills to ask and answer questions".[1] This learning model provides an opportunity for students to ask questions about material that is not yet understood and provides opportunities for other students to answer questions from their friends.

The GQGA model students are able to listen, observe, ask questions, and collaborate with group friends to select the questions in papers 1 and 2. This is in accordance with the opinion of Hamruni that: Giving Question and giving answer learning is active learning that involves students in improving listening skills, observing, proposing and discussing learning material.[6]

The GQGA learning model is a learning model that stimulates active students in the classroom. The use of this learning model can foster the courage and activeness of students in asking questions. As revealed by Djamarah "the GQGA learning model is very well used to involve students in repeating the material provided.[2]

The results obtained in the first cycle of learning with 2 meetings that there are still many shortcomings so that the results of the first cycle have not yet reached the expected results. These deficiencies are caused by two factors: the teacher factor and the student factor. As for the teacher factor, the teacher forms a heterogeneous group based on the level of intelligence of the child, the teacher submits each group to choose questions on papers 1 and 2 and the teacher conveys each group to read the questions they have selected. Whereas on the factors students write questions in paper 1 about what is not yet understood and paper 2 about what they can explain, students pay attention to the division of groups, pay attention to the teacher's explanation.

The results of observations indicate that the implementation of learning has not been successful because it has not yet reached the indicator of success established by researchers, namely $75 \%$ of all learning steps carried out with good qualifications. Meanwhile, the results of the evaluation in the first cycle showed that students who scored $\geq 75$ were 14 students or the percentage of completeness was $60.8 \%$ and students who scored $<75$ were 9 students or $39.1 \%$. Seeing the shortcomings that still exist and the achievement of student learning outcomes in social studies learning in the first cycle has not met the standard indicators of 
research success that have been set by researchers that is students who scored $\geq 75$ have not reached $75 \%$ of the total number of students.

In the second cycle, which was carried out with 2 meetings, it was found that the activities covered by the GQGA learning model had been successfully implemented. This can be seen from the evaluation of cycle II which shows that students who scored $\geq 75$ were 19 students or the percentage of completeness was $82.6 \%$ and students who scored $<75$ were 4 students a percentage of $17.3 \%$. This shows that $75 \%$ of the total number of students have achieved the indicators of success set by researchers.

The success of the action from cycle I to cycle II is because the teacher can implement the learning design in accordance with the steps of the GQGA learning model that is applied so that students' social studies learning outcomes have increased. The learning objectives set have been achieved well, and students' understanding has improved. in social studies learning, especially in the matter of the struggle to defend Indonesian independence, indicates that the GQGA learning model can be used as one of the learning models in improving social studies learning outcomes of students in primary schools.

\section{Conclusion}

Based on the formulation of the problem, the results of the analysis and discussion, the results of this study can be concluded that learning by applying the Giving Question and Getting Answer learning model can improve the social learning outcomes of fifth grade students of SD Inpres 12/79 Lonrae, Tanete Riattang Timur District, Bone Regency. This can be seen from the student learning outcomes that have increased in each cycle. When compared with the ability of students in the first cycle in the sufficient category (C), while the second cycle increased to the good category (B).

\section{Acknowledgment}

The author thank the head of program study PGSD FIP UNM, Azma is the student PGSD for advice in writing of this manuscript. Headmaster and teachers of SD Inpres 12/79 Lonrae sebagai tempat pelaksanaan penelitian.

\section{Reference}

[1] A. Suprijono, Cooperative Learning: Teori dan Aplikasi PAIKEM. Yogyakarta: Pustaka Pelajar, 2015.

[2] Djamarah, Guru dan Anak Didik dalam Interaksi Edukatif. Jakarta: PT. Rineka Cipta, 2014.

[3] S. S. dan S. Arikunto, Penelitian Tindakan Kelas. Jakarta: Bumi Aksara, 2015.

[4] Kunandar, Langkah Muda Penelitian Tindakan Kelas: Sebagai Pengembangan Profesi Guru. Jakarta: RajaGrafindo Persada, 2012.

[5] S. dan C. S. Arikunto, Evaluasi Program Pendidikan. Jakarta: Bumi Aksara, 2014.

[6] Hamruni, Strategi Pembelajaran. Yogyakarta: Insan Madani Jihad, 2011. 
